\title{
Immunological comparison between human and rat plasminogen activators in blood and the vessel wall
}

\author{
A KJAELDGAARD, ${ }^{*}$ B LARSSON,${ }^{*}$ B ÅSTEDT $\dagger$ \\ From the Departments of Obstetrics and Gynaecology, Huddinge* and Lund $\dagger$ University Hospitals, Sweden
}

SUMMARY To evaluate the rat as an experimental model for plasminogen activator research, the ability of antibodies specific for human tissue type plasminogen activator and urokinase to suppress the plasminogen activator activity in whole plasma and in the vessel wall was studied in both rat and man. Plasminogen activator activity in plasma was assayed on fibrin plates containing plasminogen. Plasminogen activator in the vessel wall was shown by the fibrin slide technique. Antibodies against human tissue type melanoma cell activator and urokinase were raised in goats and mixed into the fibrin film or the fibrin plates. In both species antibodies to melanoma cell activator were able to suppress the plasminogen activator activity completely in plasma and in the vessel wall. Anti-urokinase, however, had no suppressing effect. In rat plasma the inhibitory effect on the fibrinolytic activity was seen only with high concentrations of antibodies against melanoma cell activator, which suggests that rat plasminogen activator in plasma and vessel walls is similar to, but not identical with, human tissue type plasminogen activator.

Plasminogen activators arecific proteolytic enzymes-which convert the inactive plasminogen *...into active plasmin, thereby initiating the fibrinolytic system.' In tissues and body fluids two types of plasminogen activator have been identified: tissue like and urokinase like plasminogen activators. In blood the tissue like plasminogen activator is the main type present, and there are only small amounts of urokinase like plasminogen activators. ${ }^{23}$ The fibrinolytic system can also be activated by an additional mechanism that is dependent on factor XII, high molecular weight kininogen, and prekallekrein. ${ }^{4}$

Most malignant tumours produce urokinase like plasminogen activators. ${ }^{56} \mathrm{~A}$ melanoma cell line has been found to produce a tissue like plasminogen activator, which is similar to and cross reacts with the tissue like plasminogen activators from the human uterus..$^{78}$ Cultures of this melanoma cell line have made it possible to obtain plasminogen activator in sufficient amounts for immunisation and further research: In human plasma, the plasminogen activator activity was suppressed by antibodies directed against tissue like plasminogen activators

Accepted for publication 11 July 1984 from human uterus, porcine heart, or human melanoma cells. ${ }^{9-11}$ In tissues, such as the ureter and the vein wall, the plasminogen activator activity was suppressed by antibodies specific for tissue like plasminogen activators, whereas antibodies to urokinase had no inhibitory effect. ${ }^{12}{ }^{13}$ In fetal organ cultures, however, urokinase like plasminogen activators as well as tissue like plasminogen activators were secreted. Cultures of fetal aorta were an exception as they produced only tissue like plasminogen activators. ${ }^{14}$

Variations in the fibrinolytic activity similar to those recorded in man have been reported in rats after administration of hormones and vasoactive drugs. ${ }^{15}{ }^{16}$ In vivo, complete lysis of fibrin deposits or occlusive thrombi has been described after the administration of tissue like plasminogen activators. ${ }^{17} 18$ Rat clots, however, in comparison to human ones, were less susceptible to the lytic activity of plasminogen-activator in vitro. ${ }^{18}$

The aim of this comparative study on man and rats was to characterise the blood and vascular plasminogen activators immunologically in order to evaluate the rat as an experimental model for plasminogen activator research. Antibodies against human low molecular weight urokinase and against melanoma cell. activator were used. 


\section{Material and methods}

COLLECTION OF BLOOD AND VESSEL SPECIMENS Human blood was obtained by venepuncture from two volunteers after venous occlusion for 3 and 10 min. Rat blood was collected after decapitation of two Wistar and two Sprague-Dawley rats. In both species, $6 \mathrm{ml}$ blood was collected in plastic tubes containing $1 \mathrm{ml} 0 \cdot 1 \mathrm{M}$ sodium citrate and immediately centrifuged at $2500 \mathrm{rpm}$ for $10 \mathrm{~min}$. Biopsy specimens, about $1 \mathrm{~cm}$ long, from two dorsal foot veins in man and from the vessels of the hind foot from four rats were sealed and immediately frozen in liquid nitrogen.

DETERMINATION OF PLASMINOGEN ACTIVATOR ACTIVITY

Fibrinolytic activity in whole plasma was assessed by the fibrin plate technique. ${ }^{19}$ Citrated whole plasma $(30 \mu \mathrm{l})$ was applied to unheated fibrin plates containing plasminogen rich human fibrin. After $18 \mathrm{~h}$ incubation at $37^{\circ} \mathrm{C}$ the diameter of the lytic zones was measured; the results were expressed in $\mathrm{mm} .^{20}$ Fibrinolytic activity in the vessel walls was determined by a modification of Todd's histochemical fibrin slide technique. ${ }^{21}$ Using a cryostate microtome, cross sections ( $8 \mu \mathrm{m}$ thick) were collected on glass slides and covered with a thin plasminogen rich fibrin film obtained by the addition of thrombin (Topostatin, Roche) to human fibrinogen (KabiVitrum). After a preincubation period of $30 \mathrm{~min}$ at $21^{\circ} \mathrm{C}$, the fibrin slides were incubated in a moist chamber for 30,60 , and $120 \mathrm{~min}$ and then fixed and stained. Plasminogen activator activity in the sections was evident by zones of clearing, surrounded by a darkly stained fibrin film.

ANTIBODIES TO MELANOMA CELL ACTIVATOR Pure melanoma cell activator was obtained from the medium of Bowes melanoma cell line. The melanoma cell activator was absorbed by immunosorbent chromatography using antibodies against porcine tissue activator, eluted with potassium thiocyanate, and finally purified by chromatography on arginine-Sepharose and gel filtration as described previously. ${ }^{12}$

Antiserum to melanoma cell activator was raised in a goat by twice injecting subcutaneously at an interval of three weeks $150 \mu \mathrm{g}$ of purified, electrophoretically homogeneous melanoma cell activator, emulsified with Freund's complete adjuvant. The antiserum gave a single precipitation line with melanoma conditioned culture medium in the gel diffusion test. IgG from the serum of immunised goat and normal goat was purified by ammonium sulphate precipitation, DEAE-Sephadex chroma- tography, and Sephadex G-200 gel filtration as described previously. ${ }^{12}$ One milligram of total $\mathrm{IgG}$ completely suppressed the activity of $0.07 \mathrm{mg}$ pure melanoma cell activator.

\section{ANTIBODIES TO UROKINASE}

Urokinase (10 000 Ploug units), obtained from Lövens, Copenhagen, was further purified by p-aminobenzamidine-Sepharose chromatography. ${ }^{22}$ High and low molecular weight urokinase were separated by gel filtration. IgG from antiserum raised to low molecular weight urokinase was prepared as described for melanoma cell activator.

INCORPORATION OF IgG INTO THE FIBRIN SLIDES AND PLATES

Normal goat IgG (control IgG), antibodies to melanoma cell activator, and antibodies to low molecular weight urokinase were incorporated into the fibrin by mixing the purified IgG fractions with the human fibrinogen before the addition of thrombin. In the fibrin plates the IgG fractions were diluted $1 / 100,1 / 1000$, and $1 / 6000$, while the final dilution in the fibrin slides was $1 / 100$. Fibrinolytic activity in whole plasma on the fibrin plates containing IgG were determined in duplicate, with the controls determined in triplicate.

\section{Results}

The spontaneous fibrinolytic activity in plasma applied to fibrin plates with and without antibodies is shown in the Table. In human plasma antibodies to melanoma cell activator completely suppressed the fibrinolytic activity after venous occlusion for $3 \mathrm{~min}$. After $10 \mathrm{~min}$ occlusion, the fibrinolytic activity was hardly measurable on addition of melanoma cell activator at the 1/6000 dilution. In all rat plasma samples the fibrinolytic activity was completely suppressed by antibodies to melanoma cell activator in the $1 / 100$ dilution. No inhibitory effect of antibodies to melanoma cell activator was seen at greater dilutions. In both species the fibrinolytic activity in plasma samples applied to fibrin plates containing normal IgG or anti-urokinase varied within the range of the control plates as shown in the Table.

In the control fibrin slides the lysed areas over the vessel sections increased with incubation time. No inhibitory effect on the plasminogen activator activity in the vessel wall was seen after the addition of anti-urokinase or control IgG to the fibrin film. On the contrary, even at the shortest incubation period the fibrinolytic activity of human and rat vessel walls was completely suppressed in the fibrin films containing antibodies to melanoma cell activator. The absence of lysis in the fibrin films with antibodies to 
Fibrinolytic activity in man after venous occlusion (VO) and in active rats as determined on fibrin plates with and without antibodies and control IgG incorporated in the dilutions $1 / 100(A), 1 / 1000(B)$, and $1 / 6000(C)$.

\begin{tabular}{|c|c|c|c|c|c|c|c|c|c|c|c|c|}
\hline \multirow[t]{2}{*}{ Plasma samples } & \multirow[t]{2}{*}{ No } & \multicolumn{2}{|c|}{ Control } & \multicolumn{3}{|c|}{ Control IgG } & \multicolumn{3}{|c|}{ Anti-urokinase } & \multicolumn{3}{|c|}{$\begin{array}{l}\text { Antibodies to melanoma } \\
\text { cell activator }\end{array}$} \\
\hline & & Mean & (range) & $\boldsymbol{A}$ & $\boldsymbol{B}$ & $C$ & $\boldsymbol{A}$ & $\boldsymbol{B}$ & $C$ & $\boldsymbol{A}$ & $\boldsymbol{B}$ & $C$ \\
\hline $\begin{array}{l}\text { Man } \\
\text { VO (3 min) } \\
\text { VO (10 min) } \\
\text { Rat }\end{array}$ & $\begin{array}{l}1 \\
1\end{array}$ & $\begin{array}{l}6 \cdot 5 \\
9 \cdot 0\end{array}$ & $\begin{array}{l}(5 \cdot 0-7 \cdot 5) \\
(8 \cdot 0-11 \cdot 0)\end{array}$ & $\begin{array}{r}7 \cdot 0 \\
10 \cdot 5\end{array}$ & $\begin{array}{r}6 \cdot 5 \\
11 \cdot 5\end{array}$ & $\begin{array}{r}6 \cdot 0 \\
10 \cdot 0\end{array}$ & $\begin{array}{l}5 \cdot 0 \\
7 \cdot 5\end{array}$ & $\begin{array}{l}6 \cdot 5 \\
7 \cdot 0\end{array}$ & $\begin{array}{l}5 \cdot 0 \\
8 \cdot 5\end{array}$ & $\begin{array}{l}0 \\
0\end{array}$ & $\begin{array}{l}0 \\
0\end{array}$ & $\begin{array}{l}0 \\
2 \cdot 0\end{array}$ \\
\hline $\begin{array}{l}\text { Wistar } \\
\text { Sprague-Dawley }\end{array}$ & $\begin{array}{l}2 \\
2\end{array}$ & $\begin{array}{l}5 \cdot 5 \\
5 \cdot 5\end{array}$ & $\begin{array}{l}(4 \cdot 0-6 \cdot 0) \\
(4 \cdot 5-6 \cdot 5)\end{array}$ & $\begin{array}{l}6 \cdot 0 \\
7 \cdot 0\end{array}$ & $\begin{array}{l}6 \cdot 0 \\
5 \cdot 5\end{array}$ & $\begin{array}{l}6 \cdot 0 \\
6 \cdot 0\end{array}$ & $\begin{array}{l}5 \cdot 5 \\
5 \cdot 5\end{array}$ & $\begin{array}{l}6 \cdot 0 \\
4 \cdot 5\end{array}$ & $\begin{array}{l}6 \cdot 0 \\
4 \cdot 5\end{array}$ & $\begin{array}{l}\mathbf{0} \\
\mathbf{0}\end{array}$ & $\begin{array}{l}5 \cdot 0 \\
3 \cdot 5\end{array}$ & $\begin{array}{l}5 \cdot 0 \\
5 \cdot 0\end{array}$ \\
\hline
\end{tabular}

Values are the diameters of the lytic zones (in $\mathrm{mm}$ )
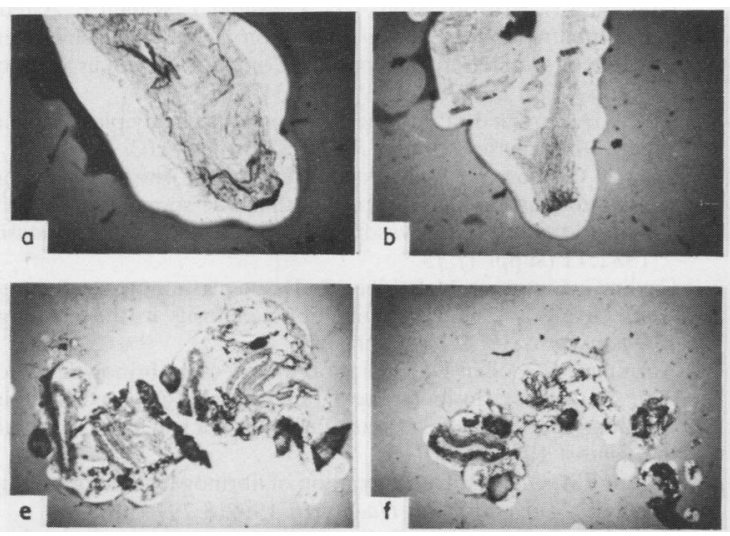
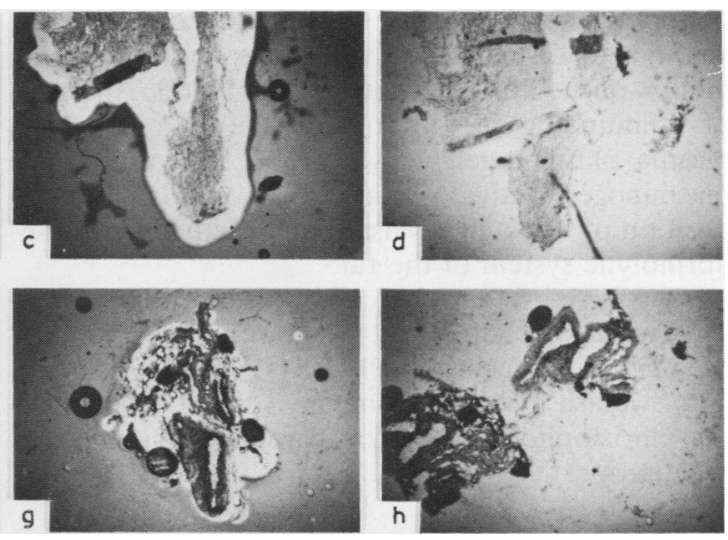

Fibrinolytic activity reflected by zones of clearing in human veins $(a-d)$ and rat vessels $(e-h) . a+e=$ controls; $b+f=$ with IgG from non-immunised goats after incubation for $120 \mathrm{~min} ; c+g=$ with $I g G$ for immunised (anti-urokinase) goats after incubation for $120 \mathrm{~min} ; d+h=$ with IgG from immunised (antibodies to melanoma cell activator) goats after incubation for $120 \mathrm{~min}$.

melanoma cell activator is illustrated in the Figure, which shows the fibrinolytic activity of the vessel specimens after 120 min incubation with and without antibodies added to the fibrin film.

\section{Discussion}

A recent report on the immunological characterisation of the plasminogen activator in the human vein wall showed that the fibrinolytic activity was initiated by tissue like plasminogen activators. ${ }^{12}$ This observation was confirmed in the present study, in which antibodies to melanoma cell activator completely suppressed the plasminogen activator activity in the vessel wall of man and also of the rat. Anti-urokinase had no inhibitory effect even after a prolonged incubation period of $2 \mathrm{~h}$.

In both species, the plasminogen activator activity in citrated whole plasma could be completely suppressed by antibodies to melanoma cell activator. No significant inhibitory effect of anti-urokinase was shown, although small amounts of urokinase in human plasma have been reported..$^{23}$ A slight inhibitory effect of anti-urokinase could be explained by similarities of the urokinase and melanoma cell activator molecules. ${ }^{24}$ Immunological similarity was thus shown between the vascular and blood plasminogen activator in man and rat. This observation implies that the relatively high fibrinolytic activity seen in active rats is probably caused by tissue like plasminogen activators being released from vessels by the same mechanism as in man. Dilution of the IgG fraction containing antibodies to melanoma cell activator resulted in the loss of its inhibitory capacity on the rat plasma, while considerably lower concentrations still suppressed the plasminogen activator activity in the human plasma samples which had higher initial fibrinolytic activity. Moreover, in a previous comparative study on plasminogen activator from human uterus and from a rat brain tumour cell line, the rat plasminogen activator was less susceptible to the inhibitory effect of antibodies specific for human uterine plasminogen activator, although these antibodies at high concent- 
rations completely suppressed the rat plasminogen activator activity. ${ }^{25}$ Hence, antibodies to melanoma cell activator seem to bind more firmly to human than to rat plasminogen activator.

In conclusion, the rat tissue like plasminogen activators are similar to, but probably not identical with, the human tissue like plasminogen activators. In rats, as in man, the tissue like plasminogen activators are present in plasma as well as in the vessel wall. The firmer binding of antibodies against melanoma cell activator to human plasminogen activator indicates minor species related differences in the structure of the otherwise closely related plasminogen activators of these two species. In man vascular plasminogen activators are important regulators of the fibrinolytic activity in blood. Absence of immunological differences between the rat plasma plasminogen activator and the vessel wall plasminogen activator indicates a similar central position of tissue like plasminogen activators in the fibrinolytic system of the rat.

This work was supported by grants from Swedish Medical Research Council (B84-17X-04523-10A) and Swedish Tobacco Company (8227). We thank Dr Christopher Korch for carefully reading the manuscript.

\section{References}

' Astrup T. Fibrinolysis: An overview. In: Davidson MB, Rowan RM, Samama MM, Desnoyers PC, eds. Progress in chemical fibrinolysis and thrombolysis Vol 3. New York: Raven Press, 1978:1-57.

${ }^{2}$ Shakespeare $\mathbf{M}$, Wolf $\mathbf{P}$. The demonstration of urokinase antigen in whole blood. Thromb Res 1979;14:825-35.

${ }^{3}$ Wijngaards G, Kluft C, Groenevald E. Demonstration of urokinase-related fibrinolytic activity in human plasma. $\mathrm{Br} J$ Haematol 1982;51:165-9.

"Murano G. The "Hageman" connection: Inter-relationships of blood coagulation, fibrino(geno)lysis, kinin generation and complement activation. Am J Hematol 1978;4:409-17.

${ }^{5}$ Roblin R, Young PL. Dexamethasone regulation of plasminogen activator in embryonic and tumor-derived human cells. Cancer Res 1980;40:2706-13.

- Vetterlein D, Young PL, Bell TE, Roblin R. Immunological characterization of multiple molecular weight forms of human cell plasminogen activators. J Biol Chem 1979;254:575-8.

${ }^{7}$ Rijken DC, Collen D. Purification and characterization of the plasminogen activator secreted by human melanoma cells in culture. J Biol Chem 1981;256:7035-41.

${ }^{8}$ Pohl G, Jörnvall H, Bergsdorf N, Einarsson M, Kaplan L, Wallén P. Differential proteolysis in preparations of tissue plasminogen activator. Comparison between the melanoma and uterine forms. Thromb Haemost 1983;50:144.

${ }^{4}$ Rijken DC, Wijngaards G, Welbergen J. Relationship between tissue plasminogen activator and the activators in blood and vascular wall. Thromb Res 1980;18:815-30.
${ }^{10}$ Angles-Cano E, Avner PR, Sultan Y. Monoclonal antibodies against porcine tissue plasminogen activator (tissue like plasminogen activators) cross-reacting with human vascular plasminogen activator (urokinase like plasminogen activators). Thromb Haemost 1983;50:57.

"Holmberg L, Nilsson IM, Wallén P, Åstedt B. Studies of the blood plasminogen activator induced by 1desamino-8-D-arginine-vasopressin with observations in von Willebrand's disease. Proc Soc Exp Biol Med 1982;170:12632.

${ }^{12}$ Ljungnér H, Holmberg L, Kjaeldgaard A, Nilsson IM, Åstedt B. Immunological characterisation of plasminogen activators in the human vessel wall. J Clin Pathol 1983;36:1046-9.

${ }^{13}$ Ljungnér $\mathrm{H}$, Bergqvist $\mathrm{D}$, Pandolfi $\mathrm{M}$, Ástedt $\mathrm{B}$. Determination and characterization of fibrinolytic activity in human ureters. Thromb Haemost 1983;50:320.

${ }^{14}$ Holmberg L, Kristoffersson A-C, Lecander I, Wallén P, Åstedt B. Immunoradiometric quantification of tissue plasminogen activator secreted by fetal organs. Comparison with urokinase Scand J Clin Lab Invest 1982;42:347-53.

is Emeis JJ. Perfused rat hind legs. A model to study plasminogen activator release. Thromb Res 1983;30:195-203.

${ }_{10}$ Prowse C, Dow R, Sheward J, Boulton F. The plasminogen activator response to direct hypothalamic stimulation in normal and congenitally vasopressin-deficient rats. Haemostasis 1982;11 (suppl 1):35.

${ }^{17}$ Cavlin G, Einarsson M, Saldeen T. Tissue plasminogen activators effectively lyses intravascular fibrin deposits in the rat lung. Haemostasis 1982;11(suppl 1): 77.

${ }^{18}$ Korninger C, Collen D. Studies on the specific fibrinolytic effect of human extrinsic (tissue-type) plasminogen activator-in human blood and in various animal species in vitro. Thromb Haemost 1981;46:561-5.

${ }^{19}$ Nilsson IM, Olow B. Determination of fibrinogen and fibrinolytic activity. Thromb Diath Haemorrh 1962;8:297-300.

2" Haverkate F, Traas DW. Dose-response curves in the fibrin plate assay. Fibrinolytic activity of proteases. Thromb Diath Haemorrh 1974;32:356-65.

${ }^{21}$ Pandolfi M, Robertson B, Isacson S, Nilsson IM. Fibrinolytic activity of human veins in arms and legs. Thromb Haemost 1968; 20:247-56.

${ }^{22}$ Holmberg L, Bladh B, Astedt B. Purification of urokinase by affinity chromatography. Biochem Biophys Acta 1976; 445: 215-22.

${ }^{23}$ Tissot JD, Schneider $\mathrm{Ph}$, Hauert J, Ruegg M. Isolation from human plasma of a plasminogen activator identical to urinary high molecular weight urokinase. $J$ Clin Invest 1982; 70:1320-3.

${ }^{24}$ Pennica D, Holmes WE, Kohr WJ et al. Cloning and expression of human tissue-type plasminogen activator DNA in $E$ coli. Nature 1983;301:214-21.

${ }^{25}$ Bykowska K, Rijken DC, Collen D. Purification and characterization of the plasminogen activator secreted by a rat brain tumor cell line in culture. Thromb Haemostas 1981;46:642-4.

Requests for reprints to: Dr A Kjaeldgaard, Department of Obstetrics and Gynaecology, Huddinge University Hospital, S-141 86 Huddinge, Sweden. 